\title{
X/Y emberkép hatása a teljesítményre változó környezetben
}

\author{
R. FILEP
}

Debreceni Egyetem Gazdaságtudományi Kar, Vezetés- és Szervezéstudományi Intézet, Vezetéstudományi Tanszék, filep.roland@econ.unideb.hu

Absztrakt. A vezetési stílus kérdésköre kutatott terület, több elmélet és modell is született az elmúlt évtizedekben, ezek közül az egyik legismertebb a McGregortól származó X/Y elmélet, amely nagy múltra tekint vissza, mégis máig foglalkoztatja a kutatókat. Az utóbbi években számos olyan elemzés is megvalósult, amely a stílusnak a szervezeti teljesítményre gyakorolt hatását vizsgálta objektív vagy szubjektív mutatók használatával. Ebben a munkámban az X/Y elmélet alapjainak, a családi vállalkozások meghatározásának és a teljesítménymérésre tett legutóbbi kísérleteknek a rövid áttekintésén túl családi vállalkozások vezetőinek körében végzett empirikus kutatásomat mutatom be. A kutatási kérdéseimmel (K1, K2) arra kerestem a választ, hogy van-e összefüggés a vezető McGregor-i emberképe és a vállalkozás teljesítménye között. A teljesítmény mérôszámaként korábbi kutatások nyomán objektív számviteli adatot, az értékesítés nettó árbevételét vettem alapul, a 2008-as gazdasági válság idején a vállalkozók vezetői is elsődlegesen ebben - az értékesítési forgalom változásában - mérték a válság hatásait. A korábbi, X/Y emberkép hatásait vizsgáló kutatások a válság lehetséges befolyásoló hatásait nem vették figyelembe, indokolt lehet ilyen tekintetben is elemzéseket végezni, ezért az első kérdésemben (K1) az X/Y emberkép és a 2008/2012 -i teljesítmény közötti összefüggést vizsgáltam, ezzel lehetőségem nyílt a 2008-as gazdasági válság induláskori (2008) és a vezetők előzetes várakozása szerint fellendülést hozó 2012-es év teljesítményének összevetésére. A kapott eredmények a korábbi kutatási eredményekhez hasonló képet mutatnak, az Y elmélet képviselői eredményesebbek, amelyet a kereszttábla-elemzés szignifikáns eredményei is megerősítettek. Második kérdésemben (K1) a gazdasági válság időszakának átugrásával a K1-hez képest más időhorizonton (2008/2017) vizsgáltam meg az X/Y elmélet szerinti lehetséges összefüggést. Ez utóbbi (K2) esetben a K1-től eltérően statisztikailag nincs kimutatható összefüggés a változók között, viszont az arányok arról tanúskodnak, hogy az Y emberképpel rendelkezők ebben az időtávban is sikeresebbek forgalomnövelés tekintetében. Az attitüdök nagyon nehezen formálhatók, viszont az X emberképpel rendelkező vezetőknek érdemes lehet felülvizsgálni az emberekrôl alkotott vélekedésüket, változtatni a hozzáállásukon, mert az eredményekből kitünik, hogy mérhetően sikeresebb az, aki Y emberképpel rendelkezik. A vállalkozások többségénél aktuálissá váló generációváltás esetében a kapott eredmények tükrében azt is érdemes megfontolniuk a stafétát átadó vezetőknek, hogy milyen emberképpel rendelkező utódra bízzák a vállalkozás további irányítását.

Abstract. The question of different management styles is a well researched area with several theories and models appearing in the past decades, one of the best known of which is McGregor's X/Y theory, which although has existed for a long time, is still an area that interests researchers. A number of analyses have been carried out in the recent years to examine the effect of leadership styles on organisational performance using objective or subjective indicators. In my work, in addition to a brief overview of the basics of $X / Y$ theory, the definition of family businesses and the recent experiments on performance measurement, I present my empirical research 
among family business leaders. Through my research questions $(K 1, K 2)$ I was aiming to find out if there is a relationship between McGregor's leadership images and the performance of the business. To measure the performance, I used previous researches' objective accounting data showing the net income from sales. During the economic crisis of 2008, the impact of the crisis was measured primarily by the managers of businnesses this way, by the change of sales turnover. Previous research into the effects of theory $X / Y$ did not take into account the possible influencing effects of the crisis; it may also be appropriate to carry out analyses in this respect, therefore, in my first question (K1) I examined the link between the X/Y image and the 2008/2012 performance. This enabled me to compare the performance of the initial period of the economic crisis of 2008 and the performance of the year 2012, expected to be booming by leaders. The results show a similar picture to the results of previous researches, the representatives of $Y$ theory are more successful, which is also confirmed by the significant results of the cross-table analysis. In my second question (K2), I examined the possible link between the X / Y theory and another time horizon (2008/2017) compared to K1, by skipping the period of the economic crisis. In this case (K2), unlike K1, there is no statistically significant correlation between variables however the proportions testify that $Y$ style leaders are more successful in this time horizon, too in terms of increase of income. Attitudes are very difficult to form, however X style leaders may be worth reviewing their beliefs about people and changing their attitude, because the results show that $Y$ style leaders are measurably more successful. In case of generation changes currently occurring with the majority of businesses in light of the received results, it is also worthwhile for business leaders handing over their responsibility to consider the leadership style of their successor.

\section{Bevezetés}

Több tényező is befolyással van a szervezetek eredményes működésére, többek között a vállalkozás tevékenysége, az iparág jellemzői, a gazdaság ciklikus változása, a vezető magatartása és vezetési stílusa. Berde (2003) írása alapján a vezetési stílus annak módját jelenti, ahogyan a vezető a hatalmát gyakorolja. Azokat az eszközöket és módszereket foglalja magában, amelyekkel a vezetők hatást gyakorolnak a beosztottakra. Dajnoki (2015) szerint fontos, hogy egy vezető tisztában legyen a saját vezetési stílusával és képes legyen az irányítása alá tartozó beosztottakon rugalmasan alkalmazni. Ebben a munkámban a vezető magatartását, stílusát a McGregortól származó $\mathrm{X} / \mathrm{Y}$ elmélet tükrében vizsgálom, amely nagy múltra tekint vissza, mégis máig foglalkoztatja a kutatókat. Az X/Y elméletnek, a családi vállalkozások meghatározásának és a teljesítménymérésre tett legutóbbi kísérleteknek a rövid áttekintését követően a családi vállalkozások vezetőinek körében végzett empirikus kutatásomat mutatom be.

A különböző iparágakban tevékenykedő vállalkozások eltérő időpontokban és eltérő mértékben élnek át kríziseket, vagy szembesülnek a változtatás kényszerével, viszont a 2008-ban kirobbant gazdasági világválság minden vállalkozásra éppen ugyanabban az időintervallumban 2008-2012 volt lényeges hatással, amelyet a magyar GDP alakulása mutat (KSH, 2018), ami csak 2013-tól került újra tartós növekedési pályára. A válság máig befolyással lehet a vállalkozásokra, de a fenti intervallumban jelentkezett ez a hatás a legintenzívebben. A teljesítmény mérőjeként pénzügyi sarokszámokat vizsgáló kutatók (Arslan és Staub, 2013) négy-öt éves intervallumokat vettek figyelembe azok alakulásánál, viszont a válság lehetséges hatásait figyelmen kívül hagyták. Szabó és Farkas (2011) munkájában nyilatkozó cégvezetők változáskezelési lépések végrehajtásával a válság 2008-as kitöréséhez képest négy éves időtávban, azaz 2012-re már fellendülést vártak, első 
kutatási kérdésemben (K1) ebben az időtávban (2008/2012) végzek elemzéseket. Második kérdésemnél azt vizsgálom, hogy a válság kitörésének évétől az abból való kilábaláshoz képest azaz a válságot „átugorva”, annak torzító hatásait kiszűrve, már az évek óta tartó GDP növekedés időszakában (2008/2017) - milyen eredmények mutatkoznak (K2). Előbbi esetben a változásokhoz való alkalmazkodás képességét, utóbbi esetben pedig a válság hatását kiküszöbölve, az időbeli előrehaladás eredményeit figyelhetjük meg. Kutatási kérdéseim (K1, K2) a következők:

K1: Van-e összefüggés a vezető X/Y emberképe és a vállalkozás 2008/2012 között mért teljesítménye között (mint a válságtűrő képesség lehetséges mérője)

K2: Van-e összefüggés a vezető X/Y emberképe és a vállalkozás 2008/2017 között mért teljesítménye között (a válság lehetséges torzító hatásainak kiküszöbölésével)

\section{Elméleti keretek}

Az alábbiakban röviden összefoglalom az X/Y elmélet hátterét és említést teszek a családi vállalkozásokhoz kapcsolódó meghatározásokról, majd bemutatok néhány példát a teljesítmény mérésére tett korábbi kísérletekből.

\subsection{X/Y elmélet}

Az X/Y elmélet McGregor nevéhez füződik, az 1960-as években fogalmazta meg ezt az elméletét. Vezetői viselkedési módokat, stílusokat vizsgáló más elméletek is születtek az elmúlt évtizedekben úgy, mint például a vezetés teljes kiterjedése modell, amelyet Avolio és Bass (1991) fejlesztettek ki és a vezetési stílusok teljes skáláját írja le a nem-vezetéstől a tranzakciós vezetésen át a transzformációs vezetésig, ennek ellenére a 60-as évekből származó McGregor-i X/Y elmélettel kapcsolatban napjainkban is számos vizsgálat születik. Russ (2011) valamint Gürbüz és szerzőtársai (2014) az X/Y emberkép és a dolgozók döntési folyamatba történő bevonásának összefüggéseit vizsgálták. Kopelman és szerzőtársai $(2008,2010)$ az X/Y emberkép új mérési módszereinek kidolgozására tettek kísérletet. Russ (2013) a kommunikációra gyakorolt hatását is vizsgálta. Az X/Y elmélet rövid összefoglalóját az 1. ábra tartalmazza. 

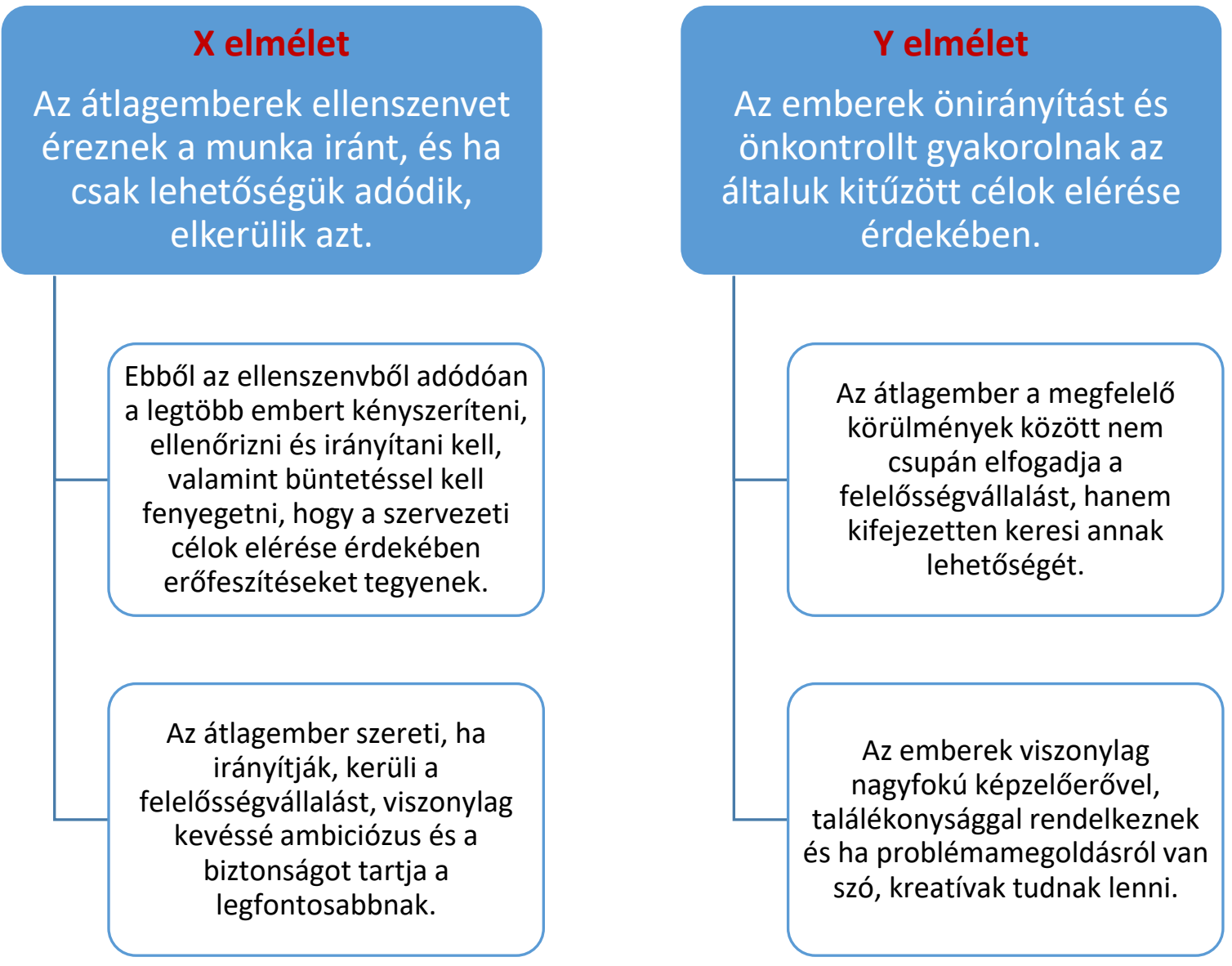

1. ábra. A McGregory X és Y elmélet rövid összefoglalása Forrás: Saját szerkesztés Spector (2010) munkája alapján

Az Y emberképpel rendelkező vezetők a szakirodalom (Spector, 2010) szerint fogékonyabbak a változásokra és az innovációra, amelyet empirikus kutatások is alátámasztanak (Arslan-Staub, 2013).

\subsection{Családi vállalkozások}

Mindeddig nem született egységes meghatározás a családi vállalkozásokra vonatkozóan, Bowman-Upton (1991) szerint akkor beszélhetünk róluk, ha két vagy több családtag tulajdonolja azt, vagy közvetlenül érintett a vállalkozás irányításában, amely Rantanen és Jussila (2011) írása alapján kiegészül egyfajta közös tulajdonérzéssel. Miller és szerzőtársai (2007) is hasonlóképpen fogalmaznak, feltételként írják elő, hogy egyidőben egy család több tagja többségi tulajdonosa vagy vezetője legyen a vállalkozásnak. Astrachan és szerzőtársai (2005) a fentieken túlmenően egy kölcsönös kapcsolatról írnak, ahol a család hozza a vállalati döntéseket, a szervezet pedig hozzájárul a jólétükhöz.

Az Európai Bizottság kiadványa (2009) a családi vállalkozások helyzetét széles körben vizsgálta, az EU tagországok mellett a tagjelölt és az Európai Gazdasági Övezethez tartozó országok is szerepeltek a mintában. Ennek a projektnek a részeként a családi vállalkozásokra vonatkozóan 
egy Európában általánosan használható meghatározásra tettek javaslatot, amely szerint cégmérettől függetlenül:

- a döntési hatalom nagy része az alapítók, az alaptőkét biztosítók vagy az ő közvetlen rokonainak a kezében van

- a család vagy rokonság minimum egy tagja formálisan is részt vesz a vállalat irányításában

A fenti definíciók szerint tágabb értelemben véve családi vállalkozásnak tekinthető az a cég, amelyben a tulajdonjog és a döntési hatalom nagy része családi kézben van és legalább egy családtag formálisan is részt vesz az irányításban.

A magyar családi vállalkozásokról viszonylag kevés az ismert és hiteles statisztika, mert a családi vállalkozás kategória nincs külön kezelve (Filep - Petheő, 2008), így számukat csak becsülni lehet, Mandl írása alapján (2008) arányuk feltehetően megfelel az Európai Unióban tapasztalt 70-80\%os mértéknek és a munkahelyek 40-50\%-át biztosítják átlagosan. Más források is (Timár, 2017) mintegy 70\%-os családi vállalkozási arányról írnak, a GDP több mint felét ők állítják elő, és a foglalkoztatottak felének biztosítanak munkahelyet. A családi vállalkozások leggyakrabban a munka intenzív ágazatokban működnek úgy, mint például a mezőgazdaság, kereskedelem, építőipar, vendéglátás (Scharle, 2000).

Az 1980-as évektől fontossá vált a változás-vezetés, sok magán és állami szervezet szembesült azzal, hogy a túlélés érdekében változtatnia kell (Ujhelyi - Filep, 2018). Az 1990-es évektől számos kisebb-nagyobb válság söpört végig a világgazdaságon (Király et al., 2008), a 2000-es évek első felében a kkv-szektor működésének általános gazdasági feltételei inkább javultak (KKV helyzete, 2007), viszont 2009-ben a gazdasági válság hatásai már kézzelfoghatóak voltak (Szabó - Farkas, 2011). 2013-tól a magyar GDP alakulása folyamatos növekedést mutat (KSH, 2018), viszont más problémák, mint a munkaerőhiány, vagy egy újabb válságtól való félelem miatti bizonytalanság mellett a generációváltás időszerűsége is új kihívások elé állította a vállalkozások vezetőit. A 80as évek végi rendszerváltás után létrehozott vállalkozások esetében napjainkban válik aktuálissá a generációváltás, ennek sikeréhez Timár (2017) szerint tekintettel kell lenni arra, hogy a leendő vezetők sok szempontból egészen másmilyenek, mint az előttük lévő generáció. A fent leírtak alapján tehát a számosságuk és a jelentőségük miatt is érdemes kutatásokat végezni ezekkel a cégekkel kapcsolatban.

\subsection{Teljesítmény mérése}

A bevezetőben részletezettek szerint több tényező is befolyással van a szervezetek eredményes működésére. A szakirodalomban a teljesítményt többféleképpen vizsgálják. Egyes kutatók (Auken et al, 2008) megkülönböztetnek objektív és szubjektív mérési módszereket. Előbbihez a különböző pénzügyi sarokszámokat sorolják úgy, mint az árbevétel és az összköltség, amelyhez kapcsolódóan Arslan and Staub (2013), valamint Szabó és Farkas (2011) is végeztek empirikus vizsgálatokat, vagy pénzügyi mutatókat, mint például a jövedelmezőségi mutatók (Capar és Kotabe, 2003; Iwata és Okada, 2011; Filep, 2018), amelyek előnye, hogy validált, nyilvános adatbázisban közzétett, vagy azokból kiszámítható, valóban objektív adatokat tartalmaz. A szubjektívekhez különböző faktorok vizsgálatát rendelik (Miron el al, 2004; Brockman és Morgan, 
2003; Auken et al., 2008) úgy, mint emberi kapcsolatok, belső folyamatok és azt hangsúlyozzák, hogy a számviteli megközelítések múltbeli történetiségen alapulnak és nem tükrözik a jövőt.

Szabó és Farkas (2011) munkájukban a válság hatásait vizsgálták a magyar KKV szektorban, amelynek során egyértelműen kiderült számukra, hogy a vállalatok a válság hatásait elsősorban a forgalom alakulásával, a forgalom visszaesésével mérik. A vállalkozók beszámolója alapján (Szabó és Farkas, 2011) a sajtóból és egyéb hírforrásokból tájékozódva a válság előjelei 2008 szeptemberében jelentkeztek, decembertől kezdtek késni a vevői kifizetések és 2009-től vált egyértelművé, hogy gazdasági válság alakult ki, azaz a 2009-es év pénzügyi adataiban figyelhető meg legelőször a válság miatti jelentősebb változás. Ennek ténye jelen kutatás következő, módszertani fejezetében leírtak miatt lényeges, a kutatási kérdések megválaszolása céljából a válság hatásait még nem mutató 2008-at célszerű bázis évként figyelembe venni az összehasonlításoknál.

\section{Anyag és módszer}

Empirikus kutatást végeztem, az 1.2 fejezetben részletezett feltételeknek eleget tévő családi vállalkozások vezetőihez juttattam el a kérdőívemet, amelyben X/Y elmélethez kötődő állításokat fogalmaztam meg, a válaszadókat kényszerválasztás elé állítottam, vagy az X vagy az Y elmélet mellett kellett letenniük a voksukat. Kényelmi mintavételt alkalmaztam, a 30 kiküldött kérdőívből 28 válasz érkezett vissza. A gyüjtött adatokhoz nyilvános céginformációs adatbázisban elérhető pénzügyi beszámoló adatait rendeltem. Az eredményesség mutatójaként Arslan és Staub (2013) munkájában leírtakhoz hasonlóan objektív pénzügyi adatot, az éves beszámolóban közzétett értékesítés nettó árbevételét (továbbiakban: árbevétel) használtam, viszont a válság lehetséges befolyásoló hatásait nem vették figyelembe, indokolt lehet ilyen tekintetben is elemzéseket végezni, ezért az alábbiakban részletezettek szerint két különböző periódusban vizsgáltam meg az X/Y emberkép és a teljesítmény összefüggéseit. A magyar GDP alakulását figyelembe véve (2. ábra) a vizsgálatomat különböző üzleti évek eredményeinek összevetésével végeztem, hogy választ kapjak a kutatási kérdéseimre (K1, K2).

Szabó és Farkas (2011) a válság hatásait a GDP alakulásával - mint erre szolgáló szokásos mutatóval - szemléltette, ezzel nemzetgazdasági szinten láthatóak annak tendenciái. A 2009-ben elvégzett kutatásukban a vezetők változáskezelési intézkedéseket tettek és 2012-re vonatkozóan már optimista becsléseik voltak a forgalomnövekedést illetően, amely eredményességét a K1 kutatási kérdésemben, már a 2012-es tényadatok birtokában tesztelni tudtam. Ennek a kutatási kérdésemnek az esetében a 2. ábrán piros színnel látható időszak jelentette a periódus kezdő és végpontját, vagyis a 2008-as válság kezdetén és a magyar GDP újra növekedési pályára állásának megelőző évében (2012-ben) mért teljesítmény közötti változást vettem figyelembe. Ahogyan az 1.1 pontban szemléltettem, a szakirodalom (Spector, 2010) szerint az Y emberképpel rendelkező vezetők jobban kezelik a változásokat, megvizsgáltam, hogy a döntéseik a saját vállalkozásukra nézve eredményesebbek-e az X emberképpel rendelkezőkénél. A 2008 és 2017-es adatok összevetésénél pedig a válság lehetséges torzító hatásait kiküszöbölve, annak induláskori (2008) adatokat a GDP fellendülési időszakában mért legfrissebb teljesítményadatokkal (2017) tudtam 
összevetni, a korábbi kutatási eredmények szerint (Arslan és Staub, 2013) az Y emberképpel rendelkező vezetők sikeresebbek árbevétel növelésében.

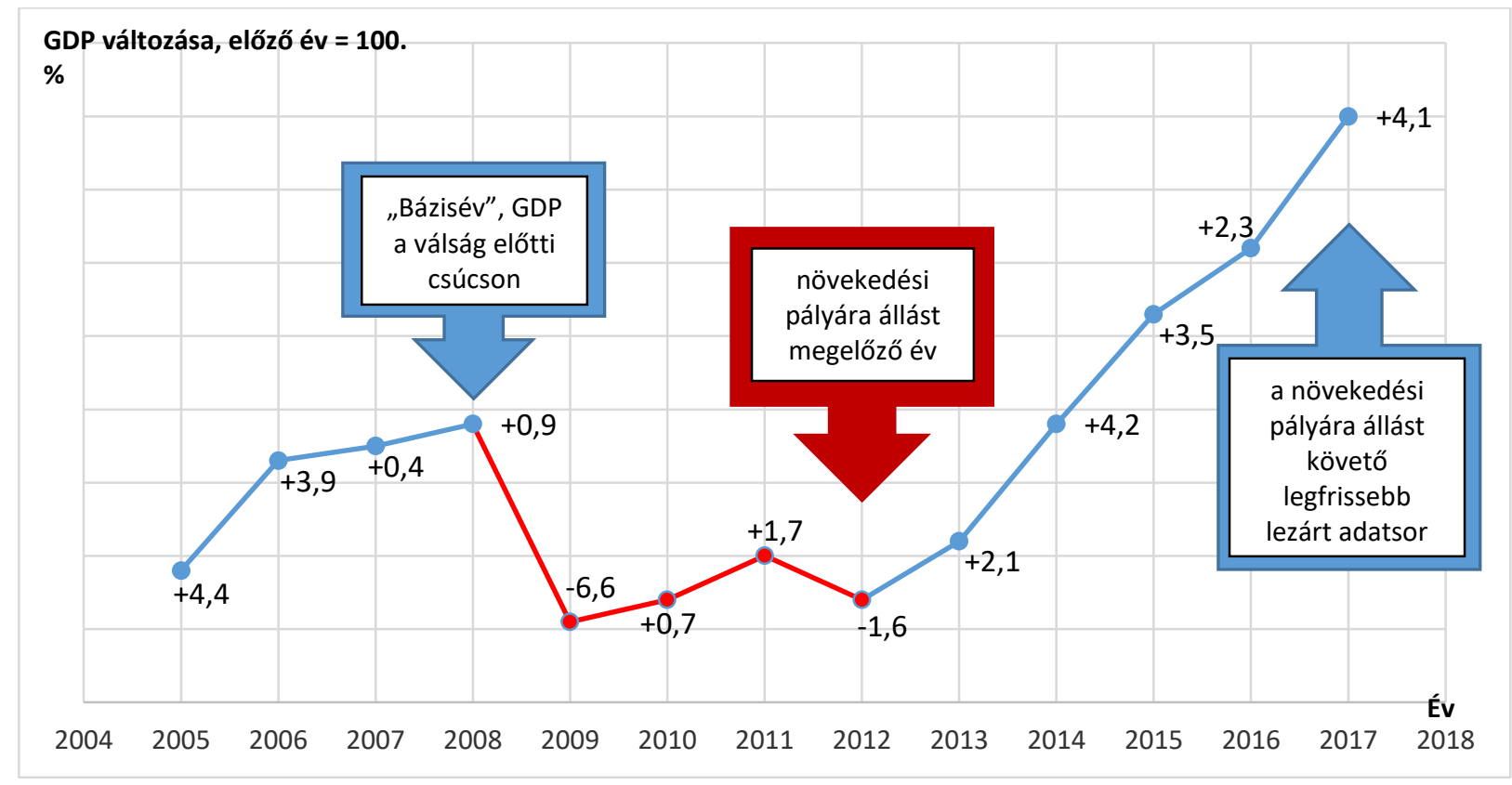

2. ábra. GDP alakulása Magyarországon

Forrás: Saját szerkesztés KSH (2018) alapján

A K1 és K2 kutatási kérdéseim megválaszolásához kereszttábla elemzést használtam. Az elemzésnél az X/Y emberkép képezte az egyik változót, a másikat pedig a K1 és K2 esetén is két különböző időpontban mért teljesítmény (árbevétel) közötti változás jelentette, ahol a teljesítmény változásának csupán az iránya került figyelembe vételre és annak mértéke nem játszott szerepet. A kapott eredményeimet a következő fejezetben mutatom be.

\section{Eredmények}

A K1 kutatási kérdés vizsgálatánál az eredmények a 3. ábrán láthatóak szerint alakultak, az Y emberképpel rendelkező vezetők többségénél a vállalkozás árbevétele nőtt, az X elmélet híveinek esetében ezzel ellentétesen alakult és csökkent. 


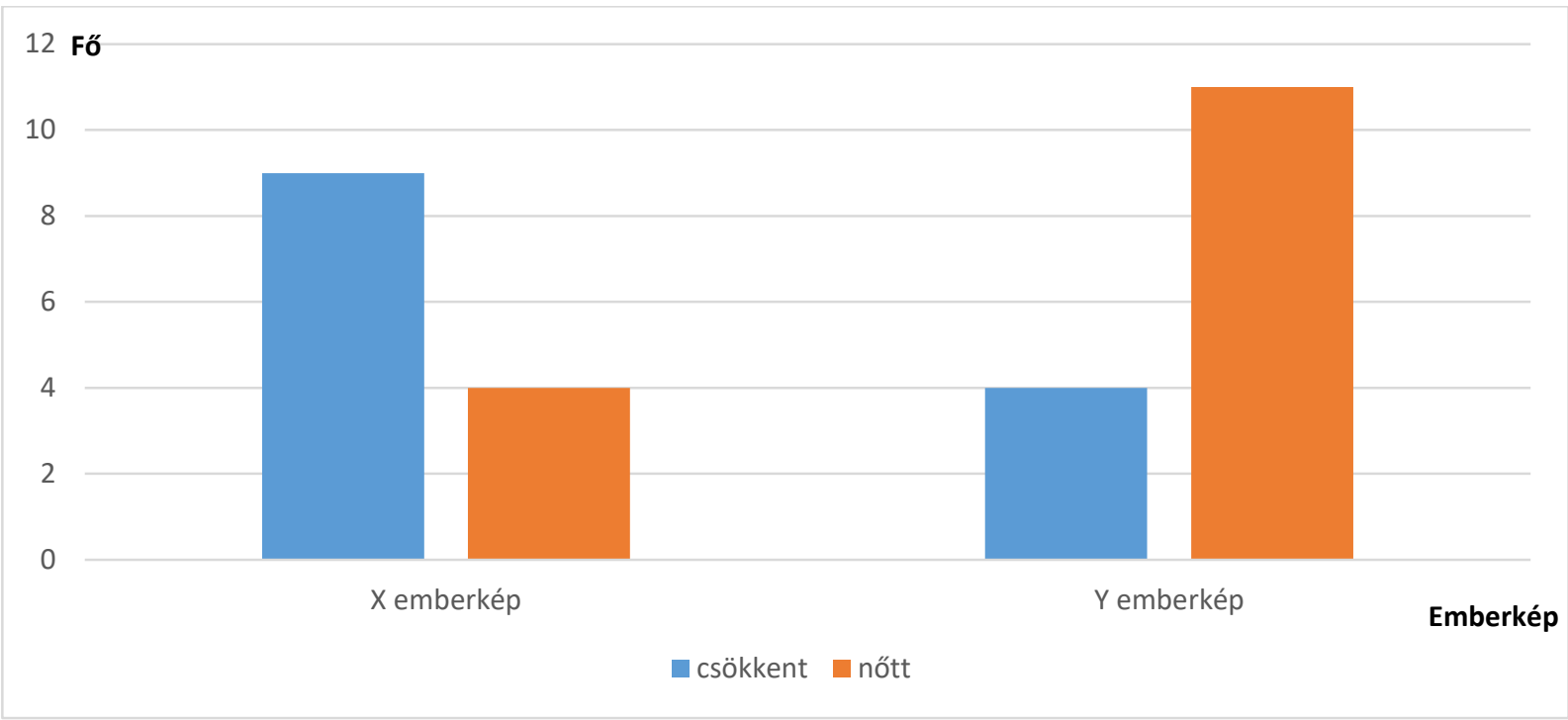

3. ábra. Kereszttábla összefüggésének megjelenítése

az X/Y emberkép és a 2008/2012-es árbevétel között

A Khi-négyzet teszt adatai alapján ( $\chi 2=5,073, \mathrm{df}=1, \mathrm{p}=0,024)$ a vezetô emberképe és az árbevétel növekedése között a 2008/2012 vizsgált időpontok vonatkozásában szignifikáns összefüggés van. A fentiekkel a (Arslan és Staub, 2013) hasonló eredményt kaptam, amely a szakirodalomban (Spector, 2010) írtakat is alátámasztja, amely szerint az Y emberképpel rendelkező vezetők jobban alkalmazkodnak a változó körülményekhez. A kapcsolat erősségét vizsgálva a 1. táblázat alapján megállapítható, hogy a két változó között az első két mutató esetében a 0,3-as gyengének tekinthetőnél erősebb, inkább a 0,5-ös közepesen erőshöz közelebbi kapcsolat figyelhető meg, a harmadik mutató esetében inkább a gyenge kapcsolat felé billen a mérleg.

\begin{tabular}{|l|l|l|}
\hline Mutatók típusa & Érték & Szinginikancia \\
\hline Phi & 0,426 & 0,024 \\
\hline Cramer V & 0,426 & 0,024 \\
\hline Kontingencia-együttható & 0,392 & 0,024 \\
\hline
\end{tabular}

1. táblázat: Kapcsolat erôsségét szemléltető mutatók

A K2 kutatási kérdés esetén az eredmények a 4. ábrán láthatóak szerint alakultak, az X és az Y emberképpel rendelkezők többségének vállalkozása esetében is nőtt az árbevétel 2008-ról 2017re. A 2017-es év egymás után már az 5. olyan év volt, amikor a megelőző évhez képest GDP növekedés volt tapasztalható, a gazdasági fellendülés hatása mindkét csoportot pozitívan érinthette. 


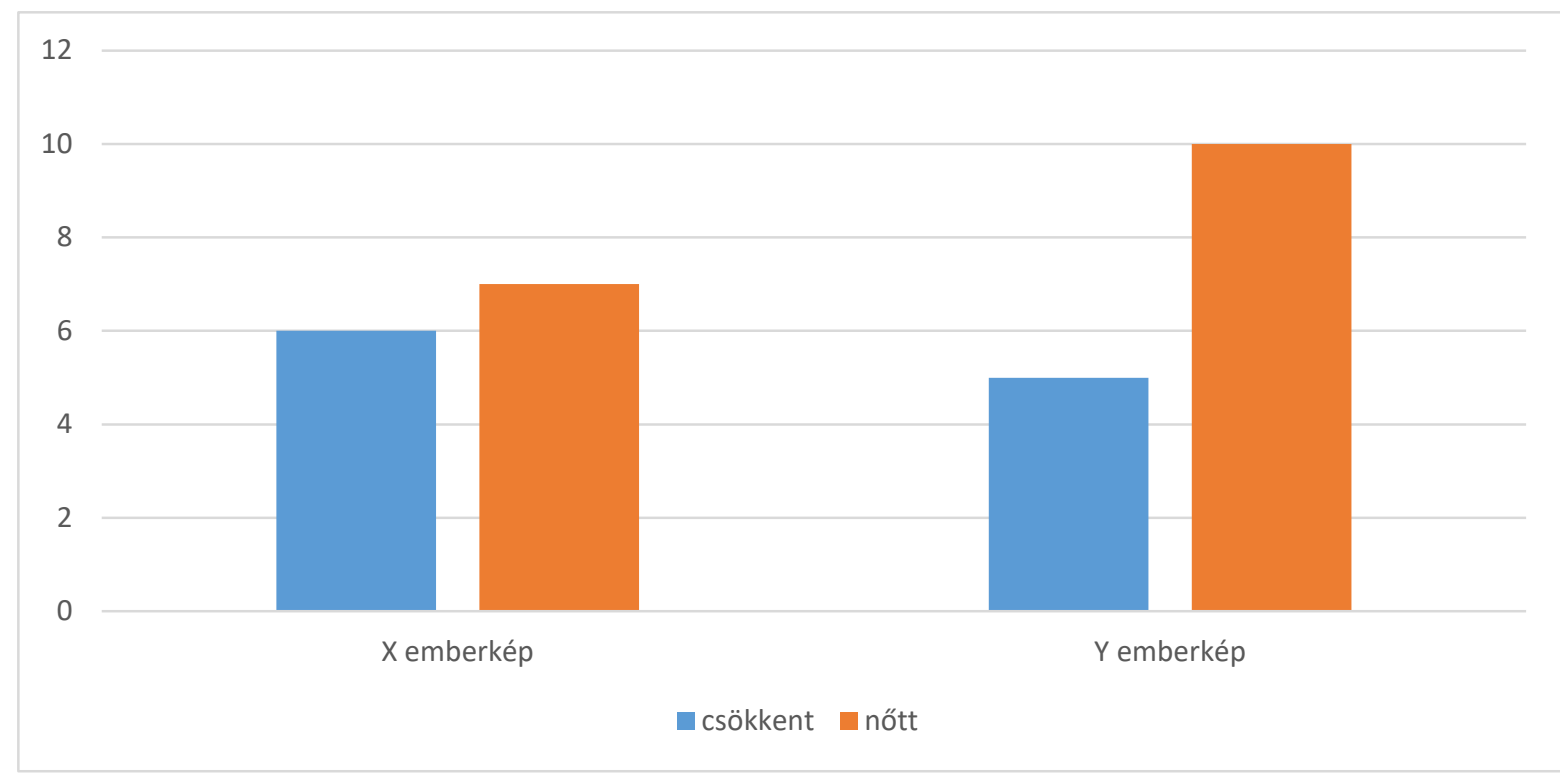

4. ábra: Kereszttábla összefüggésének megjelenítése az X/Y emberkép és a 2008/2017-es árbevétel között

A Khi-négyzet teszt adatai alapján $(\chi 2=0,480, \mathrm{df}=1, \mathrm{p}=0,488)$ a vezető emberképe és az árbevétel növekedése között a 2008/2017 vizsgált időpontok vonatkozásában nincs statisztikailag kimutatható szignifikáns összefüggés. Mivel nincs kapcsolat a változók között így annak erősségét sem vizsgáljuk tovább ilyen esetben. Ha statisztikailag kimutatható kapcsolat nincs is a változók között, a 4. ábráról azt olvashatjuk le, hogy arányaiban azért érzékelhető különbség van az X és Y emberképpel rendelkező vezetők között. Az X elmélet képviselőinek esetében a forgalmukat növelő vezetők száma alig haladja meg azoknak a számát, akik esetében csökkenés volt tapasztalható. Az Y emberképpel rendelkező, forgalomnövekedést tapasztaló vezetők száma pontosan a duplája a csökkenést tapasztaló vezetőkének.

\section{Következtetések}

Nem reprezentatív empirikus vizsgálatomban választ kaptam a kutatási kérdéseimre (K1, K2). K1 esetén az X/Y emberkép és a teljesítmény között szignifikáns összefüggés van, K2 esetében statisztikailag nincs kimutatható összefüggés a változók között, viszont az arányok arról tanúskodnak, hogy az Y emberképpel rendelkezők ebben az időtávban is sikeresebbek forgalomnövelés tekintetében.

$\mathrm{Az}$ attitűdök nagyon nehezen formálhatók, viszont az X emberképpel rendelkező vezetőknek érdemes lehet felülvizsgálni az emberekről alkotott képüket, változtatni a hozzáállásukon és máshogy gondolkodni róluk, nagyobb szabad teret engedni a beosztottaknak, mert az eredményekből kitűnik, hogy mérhetően sikeresebb az a vezető, aki Y emberképpel rendelkezik. A vállalkozások többségénél aktuálissá váló generációváltás esetében azt is érdemes megfontolniuk a stafétát átadó vezetőknek, hogy milyen emberképpel rendelkező utódra bízzák a vállalkozás további irányítását. 
A kutatás folytatásának keretében érdemes nagyobb mintán, nem csupán az X/Y, hanem más elméletek - például az 1.1 fejezetben írt vezetés teljes kiterjedése modell - függvényében is vizsgálni a vezetési stílus teljesítményre gyakorolt hatását, és mélyebbre hatóbban, faktorokat vizsgálva megállapítani az összefüggéseket, valamint teljesítménymérés vonatkozásában is több objektív mutatóra - árbevétel mellett például költségekre - és szubjektív elemekre is vizsgálatokat folytatni.

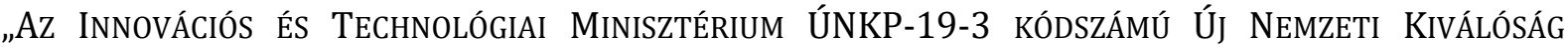

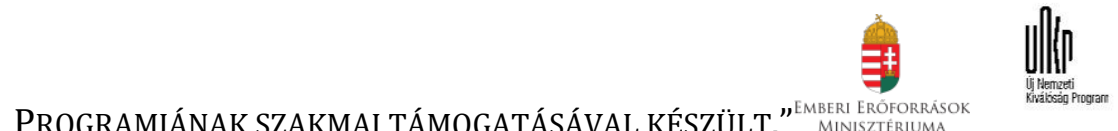
PROGRAMJÁNAK SZAKMAI TÁMOGATÁSÁVAL KÉSZÜLT.” ' MINERIIIZTERRIUMA

\section{FELHASZNÁLT IRODALOM}

[1] J. H. Astrachan, S. B. Klein és K. X. Smyrnios, "The F-PEC Scale of Family Influence: Construction, Validation, and Further Implication for Theory," Entrep. Theory Pract., vol. 29, no. 3, pp. 321-339, 2005.

[2] A. Arslan and S. Staub, "Theory X and Theory Y Type Leadership Behavior and its Impact on Organizational Performance: Small Business Owners in the Şishane Lighting and Chandelier District," Procedia - Soc. Behav. Sci., vol. 75, pp. 102-111, 2013.

[3] H. Van Auken, A. Madrid-Guijarro, D. Garcia-Perez-De-Lema, H. Van Auken, and D. GarcíaPérez-De-Lema, "Innovation and SME Performance in Spanish Manufacturing Firms Value, fair value and ethic View project Financiación a la PYME mexicana View project Innovation and performance in Spanish manufacturing SMEs," Artic. Int. J. Entrep. Innov. Manag., vol. 8, no. 1, pp. 36-56, 2008.

[4] B. J. Avolio, B.M. Bass: The full range of leadership development: Basic and advanced manuals. Binghamton, NY: Bass, Avolio, \& Associates, 280., 1991.

[5] Cs. Berde: Vezetési stílusok In: DIENESNÉ KOVÁCS Erzsébet, BERDE Csaba: Vezetéspszichológiai ismeretek. Campus Kiadó, Debrecen, ISBN 9632066405 pp.66-77., 2003.

[6] N. Bowman-Upton: Transferring management in the family-owned business. U.S. Small Business Administration. 1991. http://archive.sba.gov Letöltve: 2019.04.21.

[7] B. K. Brockman and R. M. Morgan, "The Role of Existing Knowledge in New Product Innovativeness and Performance," Decis. Sci., vol. 34, no. 2, pp. 385-419, 2003.

[8] N. Capar and M. Kotabe, "The relationship between international diversification and performance in service firms," J. Int. Bus. Stud., vol. 34, no. 4, pp. 345-355, 2003.

[9] K. Dajnoki: A vezetési stílus, mint a hatékony vezetés alapjai In: Bácsné B. É., Berde Cs., Dajnoki K.: A vezetés alapjai. Debreceni Egyetem, Debrecen, 102 p., ISBN: 9786158029032 pp. 83-96., 2015. 
[10] Európai Bizottság: Final Report of the Expert Group, Overview of Family-BusinessRelevant Issues: Research, Networks, Policy Measures and Existing Studies. Brussels, European Commission, 2009, http://ec.europa.eu/enterprise/policies/sme/promotingentrepreneurship/family-business/family_business_expert_group_report_en.pdf Letöltve: 2019.04.15.

[11] J. Filep - A. Petheő: Overview of Family Business Relevant Issues: Country Fiche Hungary. Budapest: Corvinus University of Budapest, Small Business Development Center (SBDC) 2008.

[12] R. Filep: Vezetési stílus vizsgálata MLQ segítségével a szabolcs-szatmár-bereg megyei kisvállalkozások körében. Int. J. Eng. Manag. Sci. 3 (4), 36-47, 2018.

[13] S. Gürbüz, F. Şahin, and O. Köksal, "Revisiting of Theory X and Y," Manag. Decis., vol. 52, no. 10, pp. 1888-1906, 2014.

[14] Igazságügyi Minisztérium
https://ceginformaciosszolgalat.kormany.hu/;

Céginformációs Szolgálata https://ebeszamolo.im.gov.hu/oldal/kezdolap

[15] H. Iwata and K. Okada, "How does environmental performance affect financial performance? Evidence from Japanese manufacturing firms," Ecol. Econ., vol. 70, no. 9, pp. 1691-1700, 2011.

[16] R. E. Kopelman, D. J. Prottas, and A. L. Davis, "Douglas McGregor's Theory X and Y: Toward a Construct-valid Measure," Journal of Managerial Issues, vol. 20. Pittsburg State University, pp. 255-271, 2008.

[17] R. E. Kopelman, D. J. Prottas, and D. W. Falk, "Construct validation of a Theory X/Y behavior scale," Leadersh. Organ. Dev. J., vol. 31, no. 2, pp. 120-135, 2010.

[18] J. Király - M. Nagy - E. V. Szabó: Egy különleges eseménysorozat elemzése - a másodrendű jelzáloghitelpiaci válság és (hazai) következményei, Közgazdasági Szemle, LV. évf., 573621. old., 2008.

[19] A KKV-k helyzete, Nemzeti Gazdasági és Fejlesztési Minisztérium, 2007.

[20] KSH: STADAT Bruttó hazai termék (GDP) (1960-). 2018. http://www.ksh.hu/docs/hun/xstadat/xstadat_hosszu/h_qpt001.html letöltve: 2019.04.29

[21] I. Mandl: Overview of Family Business Relevant Issues. Final Report. Wien: KMU Forschung Austria, 2008.

[22] D. Miller, I. Le Breton-Miller, R. H. Lester, and A. A. Cannella, "Are family firms really superior performers?," J. Corp. Financ., vol. 13, no. 5, pp. 829-858, 2007.

[23] E. Miron, M. Erez, and E. Naveh, "Do personal characteristics and cultural values that promote innovation, quality, and efficiency compete or complement each other?," J. Organ. Behav. J. Organiz. Behav, vol. 25, pp. 175-199, 2004.

[24] N. Rantanen and I. Jussila, "F-CPO: A collective psychological ownership approach to capturing realized family influence on business," J. Fam. Bus. Strateg., vol. 2, no. 3, pp. 139- 
$150,2011$.

[25] T. L. Russ, “Theory X/Y assumptions as predictors of managers' propensity for participative decision making," Manag. Decis., vol. 49, no. 5, pp. 823-836, 2011.

[26] T. L. Russ, "The relationship between Theory X/Y: assumptions and communication apprehension," Leadersh. Organ. Dev. J., vol. 34, no. 3, pp. 238-249, 2013.

[27] B. Spector, Implementing organizational change : theory into practice. Pearson, 2010.

[28] Á. Scharle: Önfoglalkoztatás, munkanélküliség és családi kisvállalkozások. Magyarországon. Közgazdasági Szemle, 47, 3, 250-274 o., 2000.

[29] J. Szabó and S. Farkas, "A válság hatásai a magyar kis- és középvállalati szektorban," Vezetéstudomány, XLII. Évf. 2011. 9. Szám, 2011.

[30] G. Timár: Ki kell bírni együtt, a jövő érdekében. Piac\&Profit, 2017. http://www.piacesprofit.hu/kkv_cegblog/ki-kell-birni-egyutt-a-jovo-erdekeben/ (letöltés dátuma: 2017.10.02)

[31] M. Ujhelyi, R. Filep:Változás-vezetés. Metszetek.Vol. 6 (4), 5-21, 2017. 